\title{
STUDYING IMPACTS OF USING INFORMATION TECHNOLOGY IN TRANSPORTATION SYSTEM OF COUNTRY FROM ECONOMIC STANDPOINT
}

\author{
Shahab Hassanpour \\ Faculty member at Ayatollah Borujerdi University, Civil Engineering Department, Borujerd, Iran \\ shahab.hassanpour@gmail.com \\ Naeim Ezati \\ MSc in Civil Engineering, Transportation, Department of Engineering, \\ Islamic Azad University E-Campus, Tehran, Iran
}

\begin{abstract}
In recent years and in developed societies, transportation engineers together with specialists in telecommunication and communication, electronic, computer and other fields have created Intelligent Transportation Systems (ITS) by utilizing the facilities that at the present time are known to be results of IT; ITS has a suitable and desirable infrastructure to realize and access the specified following goals. Information technology makes the corporations to use their resources and institutions in the best possible way. As investment in information technology capital for investment in capital stock is considered an ever increasing share, to understand how this investment can be compensated is also important. In the present paper impacts of information technology on transportation sector and economical aspects of it especially its impacts on the value added of transportation of provinces in sub-sector of passenger carrying was studied by using method of unbalance panel data and data gathered from 2012 until 2016. Impacts of information technology on the value added of passenger transport sector were analyzed with two types of total variables and separated variables. Results showed that investment in other than information technology, human capital, rate of population growth, investment in information technology, expenditure and investment in hardware and software, have positive and significant effect on the value added of passenger transport sector.
\end{abstract}

Keywords: information technology (IT), passenger transport, value added, panel data

\section{INTRODUCTION}

Intelligent transportation systems refer to systems that by using automatic tools and programs installed on them perform a number of control functions (controlling flow of traffic, traffic or toll regulations) or information functions (survey, informing drivers, gather information and so on). These systems improve safety, efficacy and cheapness in transportation (including road, rail, air and sea) by utilizing novel technologies such as electronic, communication and control systems (2). Intelligent control systems of intersections, messaging variable message signs (VMS), automatic reception of road tolls, automatic record of events, accidents and traffic violations, weighing while moving, informing public transport network (momentary information of passages) and navigation inside car, automatic survey from traffic parameters and other similar examples are among this collection. At these systems there is no need for continuous and simultaneous presence of human force in location of operations and the restrictions of using fixed systems ( with lower efficiency) are also eliminated. Export competitiveness and effectiveness of a country, regardless of proper productive capacities, depends highly on ability of country in exporting goods to foreign markets with lowest possible price and in accordance with conditions of customers' and importers' demands. In this regard, quality of access and transportation costs can be considered as major 
factors in determining transportation system capacity in the supply chain (4). In developing countries the cost of export is in average 2 or 3 times more than customs duties of importing country and therefore transportations costs are one of the main challenges of developing countries to move forward foreign markets. On the other hand the recent changes in information technology and communication and also electronic trading usage in manufacture and worldwide trade has provided conditions that if used properly and efficiently, most challenges existing in this industry can be eliminated (1).

\section{POSITION OF TRANSPORTATION IN GLOBAL SUSTAINABLE DEVELOPMENT}

Studying process of global economy and predicting its perspective, absolutely portraits a very competitive status in a very intensive and close situation in all aspects among countries (5). In such an atmosphere countries endeavor to use their spatial and temporal conditions properly and efficiently in order to continue competing with other countries and maintain their national interests; and besides analyzing their domestic and international status, by determining potentials, facilities, abilities and open and hidden relative advantages use them to continuo activity, competition and growth as an efficient tool. Nevertheless the important but not very clear point is the necessity of cooperation in all fields including technical, economical, administrative and communicational among countries in order to keep the present growing process and stabilize global sustainable development along with predominance of competitive atmosphere. It is by such cooperation that issues such as environmental protection, détente and fair distribution of benefits between countries and briefly utilizing global potentials can be discussed. WTO or world trade organization cab be mentioned as a relative appearance of that kind of cooperation in trading aspect. World Trade Organization has developed with a higher speed in recent two decades due to fast growth of technology, cease of military competition of cold war and its due boundaries and also higher global perception to the necessity of closeness and more cooperation. In such a way that at present time in fields of national and international trade, service sectors such as agriculture-livestock and industry-mining are among main elements of economy and if relative profitability is considered are the most important ones. Transportation as one of the other service sectors, has a prominent and fundamental role in national economic growth, development of economy and facilitating world trade and includes activities that widely participate in all economic activities and has an undeniable role (7). Direct impact of transport costs in prime cost of goods has caused that a special attention to be given to elements involved in transport process with the purpose of reducing costs, increasing speed of relocation and safety. In a way that transport is now out of its traditional way and it is looked at as an economic-serving activity. That's why at the present time export of transport services has escalated to over 300 billion dollars a year.

\section{APPLICATION OF INFORMATION AND COMMUNICATION TECHNOLOGY IN TRANSPORTATION}

The widespread changes of recent years in communication and computer field have led to major differences in different fields of human life. Human being has always used technology and human history is full of invention of communication and information technologies referred to as new or excellent technologies which have had the most impact on human life. World of communication and production of information is changing quickly and at the present time we can see their convergence even more than past; in such a way that data and information are transferred to different parts of the world and made available for users in a very quick and unimaginable time (8).

ICT or Information \& Communication Technology has undoubtedly led to a wide range of changes in all social and economic fields and its effect on human societies is in such a manner that the present world is quickly changing to an information society; a society in which wisdom, accessibility and beneficial use of knowledge play a central and decisive role. Scope of application and its effects on diverse aspects of present and future life of human societies have changed to one of the important discussions of the present world and attracted attention of many countries. ICT can be defined as: technology is collecting, organizing, saving and publishing information including audio, video, text or number which is done by computer and telecommunication tools. Regardless of various definitions and wide range of ICT usage in 
different parts of life, quick access to information and performing acts without considering geographical distances and temporal limitations are the most significant achievements of this technology. It is possible to utilize secure and available communications is an efficient way as a tool to discuss global problems. Although ICT cannot feed the hungry people or eradicate hunger or reduce death toll of children by itself, but it is a very important factor that spurs economic growth and social equity to action (6).

\section{INTELLIGENT TRANSPORTATION SYSTEMS (ITS)}

In recent years by utilizing facilities nowadays known as results of IT, the developed countries have created a suitable infrastructure for traffic specialists to access proper technologies in planning, guidance and controlling traffic by creating Intelligent Transport Systems (ITS). If we suppose that these developments and the present condition are positive, then 16 principle systems and more than 160 services are provided through ITS (5). In this regard, access to goals of transport planners will always be followed by increasing safety and relaxation while travelling, reducing costs and unfavorable environmental effects, decreasing energy consumption and unwanted delays during travel and in the end satisfying passengers and lighten traffic flow and transportation. Transport and relocation of passengers and goods, as one of the basic human needs and as a prominent and very important index have always been given a special attention in macro planning of societies. At this age which is known as "age of information explosion", communication and information technology as an efficient tool for specialists of different courses, have facilitated and expedited provision of services. In this regard, transport engineers have also endeavored to utilize IT as a suitable solution to eliminate main difficulties of traffic management and reduce its problems to minimum. In the present paper it is tried to explain a number of IT applications in transportation. In recent years and in developed societies, transportation engineers together with specialists in telecommunication and communication, electronic, computer and other fields have created Intelligent Transportation Systems (ITS) by utilizing the facilities that at the present time are known to be results of IT; ITS has a suitable and desirable infrastructure to realize and access the specified following goals:

- $\quad$ Efficient and precise management and planning in transport and traffic

- $\quad$ Optimal use of existing resources

- $\quad$ Reduction of damages and increase of safety and relaxation

- $\quad$ Reduction of energy consumption, costs and unfavorable environmental effects

- $\quad$ Reduction of travelling time and unwanted delays and finally satisfying passengers and lightening traffic and transport flow.

These goals have always been among desires and requests of planners and transport specialists and traffic engineers in using ITS.

In this regard and in a more precise way, the most important functions of ITS are as following:

- $\quad$ Management and optimization of traffic flow and lightening movement

- $\quad$ Management and control of accidents

- $\quad$ Management of electronic toll collection, parking price, ticket reservations and buy and so on

- $\quad$ Monitoring and controlling light and heavy transport

- $\quad$ Management and advanced navigation of public transport navy

- $\quad$ Management of public transportation

- $\quad$ Management and support of pedestrians and so on.

It is clear that any one of the mentioned cases could not be achieved without utilizing results of IT. For instance control and planning of traffic lights inside cities have always been one of the important problems of traffic flow optimization and management; the function of this system can be briefly explained as following: number and density of vehicles are evaluated by different sensors installed under road surfaces or edges and are sent to central control centers by communication tools such as optical fiber or wirelessly for the aim of processing and decision making. In control centers based on traffic 
management principles and calculations of phasing of lights done by related software and by taking into consideration different conditions, optimal time to stop behind light and moving in road network while light is green are processed and required orders are sent to devices controlling lights. Nowadays in many metropolises of world, using this system is common and in Tehran metropolis this system is utilized in more than 150 intersections as well. Reducing undue delays, reducing time of trip and attracting satisfaction of passengers, reducing number of accidents and creating green wave in the network are among advantages of this system. Creation of such kind of a system besides being connected to an information network or news site can easily help passenger to choose the desirable path before starting to travel and also have a significant effect on reducing traffic volume. It is evident that if such a system is developed, even cell phone mobiles that nowadays can be connected to news networks will also have the capacity to receive information and news related to traffic. It is clear that in this way a secure path away from unwanted aggregates suggested by intelligent news systems and being selected by passenger will have a desirable and positive effect on traffic flow. Besides these, reduction of vehicle's fuel consumption, time of trip and increase of the safety factor in driving and relaxation created in passenger are also favorable and permanent results of it and considered as effects of ITS advanced navigation system. However nowadays in Tehran, technique of informing drivers is done by radio and message channel and in some areas by normal news signs or variable message which are among the most preliminary methods of informing drivers the traffic condition. Some other functions of advanced navigation systems are providing information in order to select other methods, transport systems and get to destination by other transport vehicles or providing information in relation to service levels and giving services to the passenger in destination. In news systems related to transport control and planning, transferring news which may lead to abnormal conditions or accidents is of high importance; the reason is that in both situations it is possible to think of changing passenger's path and prevent sudden congestion.

\section{MAIN ECONOMIC IMPACTS OF TRANSPORTATION}

Transportation sector affects main economic variables of country such as total production, production in economic sectors, total employment, employment in economic sectors, price in various economic sectors and life cost index in a short-term, medium-term and long-term. Short-term effects include the effects related to increase or decrease of life costs, directly through transport costs of families and indirectly through the effect is has on cost of other goods and services; medium-term effects include effect of transport costs on consumption of alternative services such as communications; and long-term effects are related to change in basis of economic calculations of production and construction plans. Generally combination of production activities in every area and according to that combination of production texture, employment combination, production volume, per capita income volume and other related economic variables are affected by price changes of transport services. In economic study of transportation, impact of price changes of transport services on cost of living index is assessed as table No.1 (1):

Table No.1 Impact of Price Changes of Transport Services on Cost of Living Index

\begin{tabular}{|c|c|}
\hline Percentage of Transport Services Price Changes & Percentage of Cost of Living Index Changes \\
\hline 6 & 0.59 \\
\hline 11 & 1.12 \\
\hline 14 & 1.87 \\
\hline
\end{tabular}




\begin{tabular}{|c|c}
\hline 20 & 3.56 \\
\hline 34 & 6.49 \\
\hline 40 & 7.79 \\
\hline 5 & 6.07 \\
\hline 100 & 12.14 \\
\hline
\end{tabular}

In order to have a clearer image of transport position in economy of country, a review is made on value added and investment index in transportation sector and a brief analysis is done about function of different transportation sub-sectors including road, rail, sea and air.

\section{VALUE ADDED OF TRANSPORTATION SECTOR}

Value added of each economic sector is the most important variable that specifies its position in the whole economic activities of country. Total value added of national economy which is expressed under Gross National Product (GNP) includes a set of different economic sections that transport is also one of its constitutive sub-sections. During the years of 2011-2015, GNP has had the average annual growth of 4.3; it is while at the same period of time transport sector has had $\mathrm{n}$ average annual growth of 8.7. A comparison of the mentioned figures indicates that value added of transport sector in that time period was about 3 percent more than GNP. Studying value added share of transport sector in GNP of country indicates that this variable generally has an ascending trend.

Table No.2 Value Added of Transport Sub-Sectors of Whole Country

\begin{tabular}{|c|c|c|c|c|c|}
\hline \multirow[t]{2}{*}{ Year } & \multicolumn{3}{|c|}{$\begin{array}{l}\text { Value Added Percent of Transport Sub-Sectors as } \\
\text { Compared to the Whole Transport Sector }\end{array}$} & \multicolumn{2}{|c|}{$\begin{array}{c}\text { Value Added Percent of } \\
\text { Transport Sector as compared to } \\
\text { the Whole Country }\end{array}$} \\
\hline & Road & Rail & Air & Sea & \\
\hline & 75 & 8 & 13 & 4 & 7.6 \\
\hline & 77 & 6 & 14 & 3 & 7.7 \\
\hline & 74 & 8 & 13 & 4 & 7.4 \\
\hline & 74 & 9 & 12 & 5 & 8.2 \\
\hline & 71 & 6 & 15 & 3 & 7.5 \\
\hline
\end{tabular}

According o the figures of above table, construction budget share of transport sector from total construction budget of country is a descending trend. The reason o this descent can be opening of new horizons such as industry, telecommunication, energy, education and other fields in recent years. Therefore considering the fundamental role of transportation in realization of economic development and necessity of having efficient and capable transport network and system which can move forward with international standards, requires more attention to be given to investment in Road and Transportation section. 
Comparing process of capital and value added formation in transport section and total economy of country points out this reality that transport section has relatively higher potential which can move upward if problems such as lack of Return ON Investment (ROI) and legal limitations are eliminated.

\section{INVESTIGATING EXPENDITURE STATUS OF INFORMATION TECHNOLOGY IN TRANSPORT SECTION IN OUNTRY}

In this part by using a number of quantitative indices related to infrastructure and application of IT the condition of IT in road transport is evaluated.

\section{EXPENDITURE OF INFORMATION TECHNOLOGY IN PASSENGER TRANSPORT SECTION OF COUNTRY}

To examine expenditure status of IT in passenger transport section of Provinces, the index of expenditure of post and telecommunications to total expenditure of passenger transport is used. The amount of 99718758 Thousand Rials is spent in 2011 in whole country by passenger institutions and companies; the amount of 8954728 Thousand Rials of it is spent for post and telecommunications costs (such as telephone, fax ,...) which is equal to 1.6 of total expenditure. Diagram No.1 shows the share of post and telecommunications costs from total costs of Provinces in 2011.

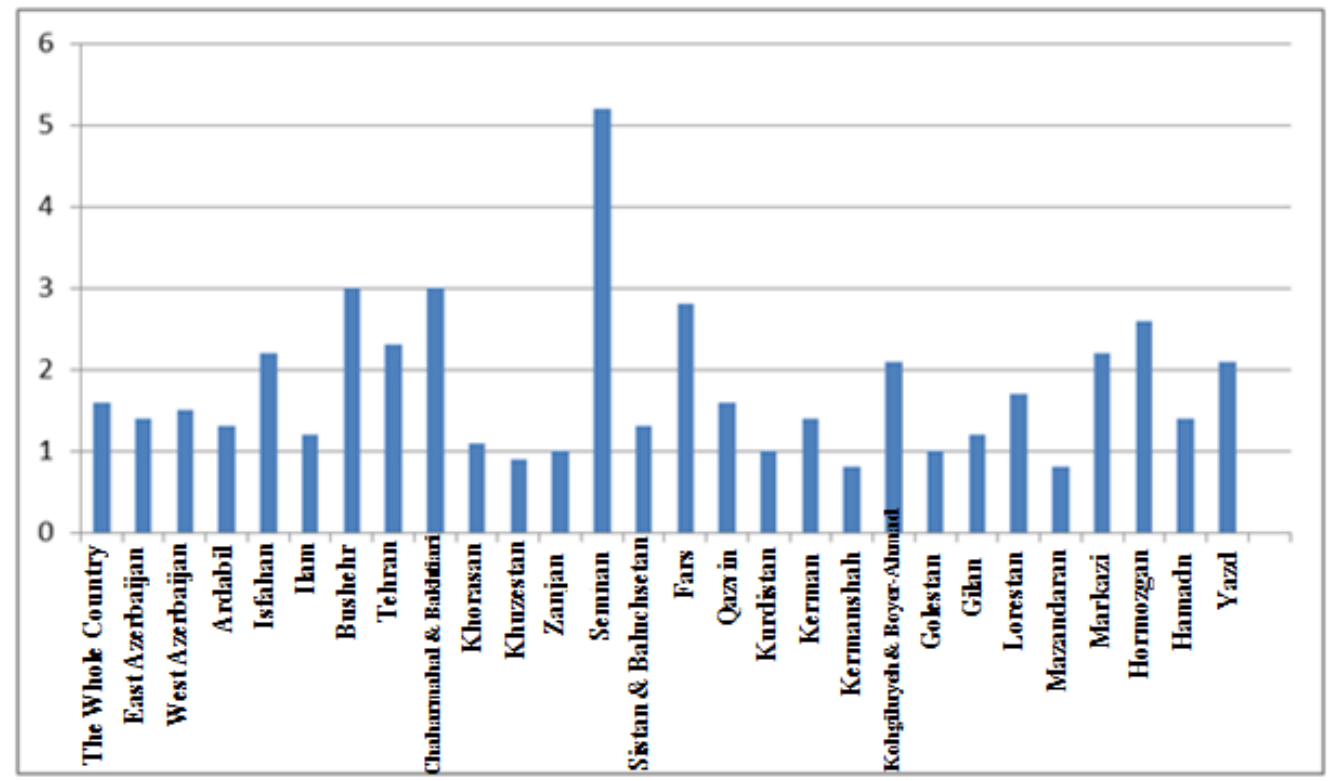

Diagram No.1 Share of Post and Telecommunications Expenditure from Total Expenditure of Provinces: 2011

As shown in Digram No.1, in 2011 the largest share of post and telecommunications expenditure from total expenditure is related to Semnan County which is equal to 5.6; next are Bushehr and Chaharmahal and Bakhtiari with a percent of about 3 percent. But the smallest share among all provinces is related to Qom, Kermanshah and Mazandaran with a share equal to 0.8.

\section{INVESTMENTS OF INFORMATION TECHNOLOGY IN PASSENGER TRANSPORT SECTION \\ Capital formation or investment refers to net increase or decrease of the value of investment property. Value of investment property increases in the event of purchase or acquisition, construction or creation and principal repairs but this value decreases in the case of sell or transfer of investment property.}


Investment property (fixed assets) are all buildings, machinery and equipment that are utilized in a work and have a lifelong of more than one year and are usually valuable. Investment property can be classified into residential and non-residential (without value of the land) buildings, vehicles, communication and telecommunication facilities and equipment, computer and equipment related to it, office furniture and furnishings, other durable office equipment, computer software and other capital assets.

\section{TELECOMMUNICATION AND COMMUNICATION TOOLS AND EQUIPMENT}

Total investment made by active passenger institutions and companies in the whole country was equal to 84102849 thousand Rials in 2013 which was reduced to about 82164600 thousand Rials in 2015 . In other words investment made in the years of 2013 to 2015 has had an average negative growth of 0.8 percent annually.

Investment made in telecommunication and communication tools and equipment has had a negative growth during the mentioned years; in a way that it decreased from 693454 thousand Rials in 2011 to 937865 thousand Rials which is indicative of a negative growth of 8.1 percent. Table No.3 shows comparison of investment made by passenger institutions and companies from 2013 to 2015.

Table No.3 Comparison of Passenger Institutions and Companies Investment from 2013 until 2015 (Thousand Rials)

\begin{tabular}{|cccc|}
\hline Description & 2013 & 2015 & The Average Annual Growth \\
\hline $\begin{array}{c}\text { Total Investment of } \\
\text { Communication and } \\
\text { Telecommunication } \\
\text { Tools and Equipment }\end{array}$ & 98956808 & 96894314 & -0.8 \\
\cline { 2 - 5 } & 86754386 & 73567430 & -8.1 \\
\hline
\end{tabular}

Reference: Center of Statistics and Calculations of the Author

The share of investment in communication and telecommunication equipment and tools of total investment of passenger institutions and companies in the whole country has decreased from 0.8 percent in 2011 to 0.65 percent in 2016. This descending trend can also be observed in many provinces of country. Provinces such as Chaharmahale Bakhtiari, Isfahan, Yazd, Gilan, Kerman and Kermanshah had the greatest decrease. The province of Yazd had the greatest decrease of share from 11.3 percent in 2011 to 1.7 percent in 2016 .

The share of investment in communication and telecommunication equipment and tools of total investment of passenger institutions and companies in Qom Province has increased from 5 percent in 2011 to about 17.7 percent in 2015. This share in Tehran Province has been almost unchanged with an amount equal to 1.2 percent. Diagram No.2 indicated share of investment in communication and telecommunication equipment and tools from total investment with provinces being separated from 2011 to 2015 . 


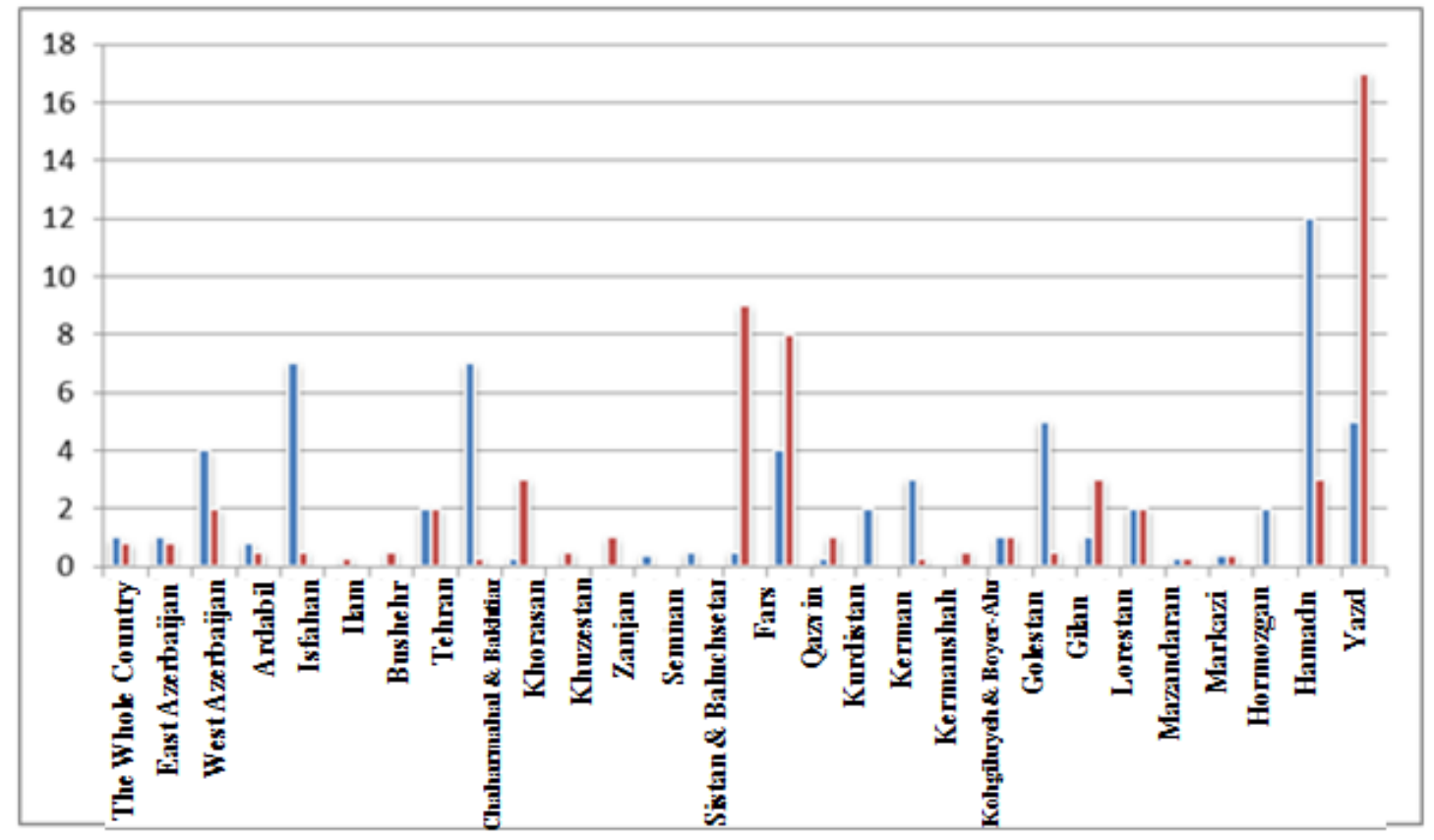

Diagram No.2 Share of Investment in Communication and Telecommunication Tools and Equipment from Total Investment with Provinces being separated from 2011 to 2015 (Percent) (Red: 2015, Blue: 2011)

\section{COMPUTER AND EQUIPMENT RELATED TO IT (HARDWARE)}

Investment in field of IT is an important index to evaluate economic approaches toward this event. Passenger institutions and companies in 2013 have allocated in total 9.3 percent of their investment to IT. Combination of IT investment is in a way that computer and equipment related to it (hardware) with 7.6 percent has the first position and next are computer software with 1 percent and communication \& telecommunication equipment with 0.7 percent. (Table No.4

Table No.4 Types of IT Investment in Passenger Institutions and Companies (Percent) in 2011 and 2015

\begin{tabular}{|cccc|}
\hline Description & 2013 & 2015 & The Average Annual Growth \\
\hline $\begin{array}{c}\text { Total Investment } \\
\text { (Thousand Rials) }\end{array}$ & 98453487 & 96345674 & -1245634 \\
\hline $\begin{array}{c}\text { IT Total Investment } \\
\text { (Thousand Rials) }\end{array}$ & 96785469 & 90451265 & -508547 \\
\hline $\begin{array}{c}\text { Communication \& } \\
\text { Telecommunication } \\
\text { Tools \& Equipment }\end{array}$ & 0.8 & 0.7 & -0.1 \\
\hline $\begin{array}{c}\text { Computer and } \\
\text { Equipment Related to it }\end{array}$ & 7.8 & 7.7 & -0.3 \\
\hline
\end{tabular}




$\begin{array}{llll}\text { Computer Software } & 0.9 & 1 & 0.1\end{array}$

Reference: Center of Statistics and Calculations of the Author

As the above table shows the amount of investment share in computer and equipment related to it from total investment is more than two other indices which is indicative of its importance among passenger institutions and companies. Nevertheless share of this index has decreased from 7.9 percent in 2013 to 7.6 percent in 2015. Moreover diagram No.3 shows investment share in computer and its equipment from total investment made in 2013 and 2015 with provinces being separated.

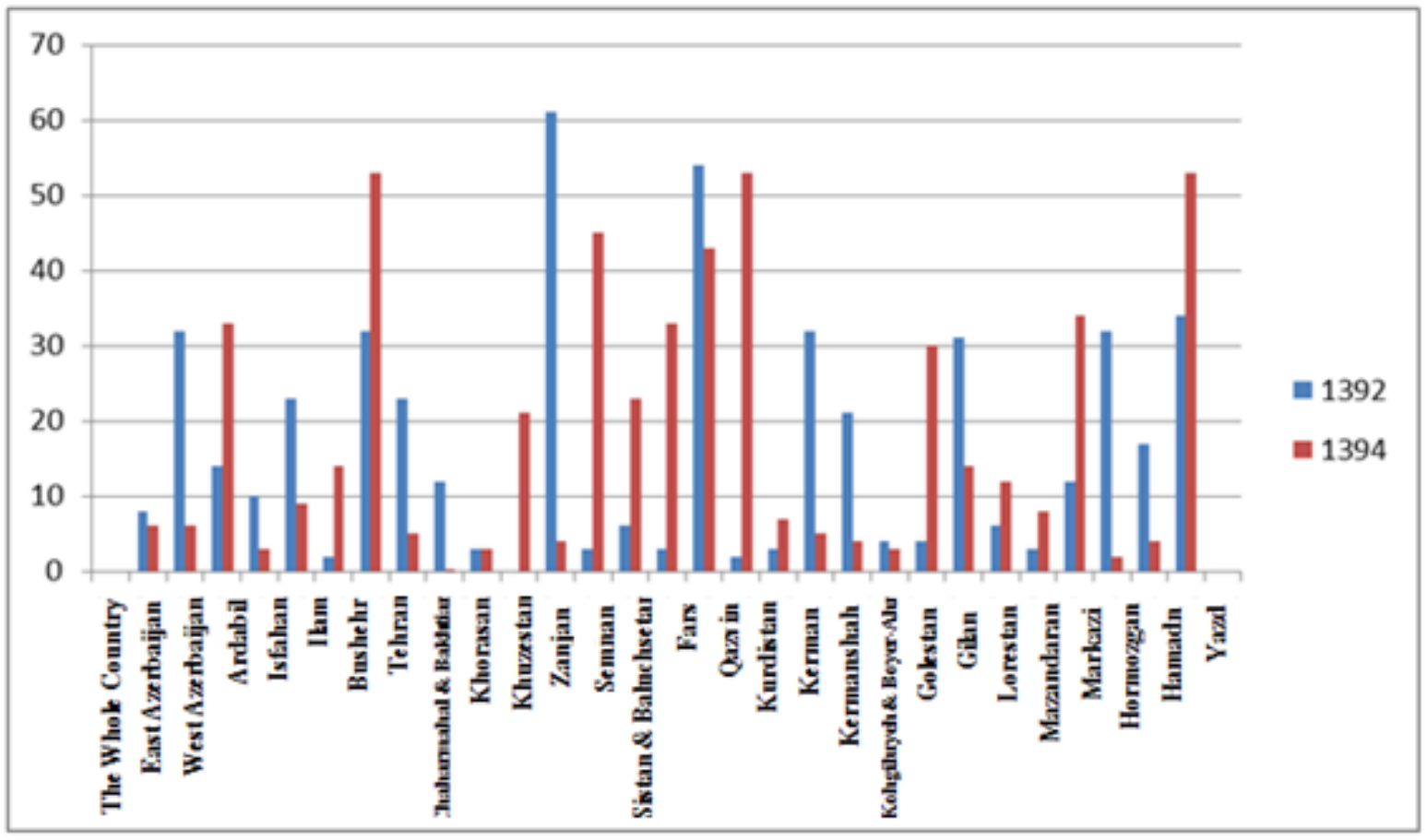

Diagram No.3 Investment Share in Computer and its Equipment from Total Investment with Provinces being separated, in 2011 and 2015

As it is clear in the above diagram is some provinces this share has been increasing and in some other decreasing. The largest increase is related to Kurdistan Province from 1.2 percent in 2013 to about 54.6 percent in 2015. But the greatest decrease is related to Zanjan Province. Investment share in computer and its equipment from total investment has decreased from 65.5 percent in 2013 to 4.9 percent in2015. In provinces such as South Khorasan, Semnan, Fars and Gilan the share has had a significant increase; this is while in provinces such as East Azerbaijan, Tehran, Kermanshah, Kohgiluyeh \& Buyer-Ahmad, Hamadan and Yazd it has had a significant decrease. In general, the overall resultant of these increases and decreases has not changed much in the whole country and has remained almost at the same level.

\section{COMPUTER SOFTWARE}

As described before, in terms of rank of investment made in IT, computer software is in the second rank. Investment in computer software, unlike two other IT investments, has had a positive growth in 2015 as compared with 2013 and has increased from 831456 thousand Rilas to 964892 thousand Rials which indicates that this investment has allocated to itself about 3.3 percent in average annually. Of course 
investment share of computer software from total investment has not changed much in provinces except in a few number of provinces (Diagram No.4)

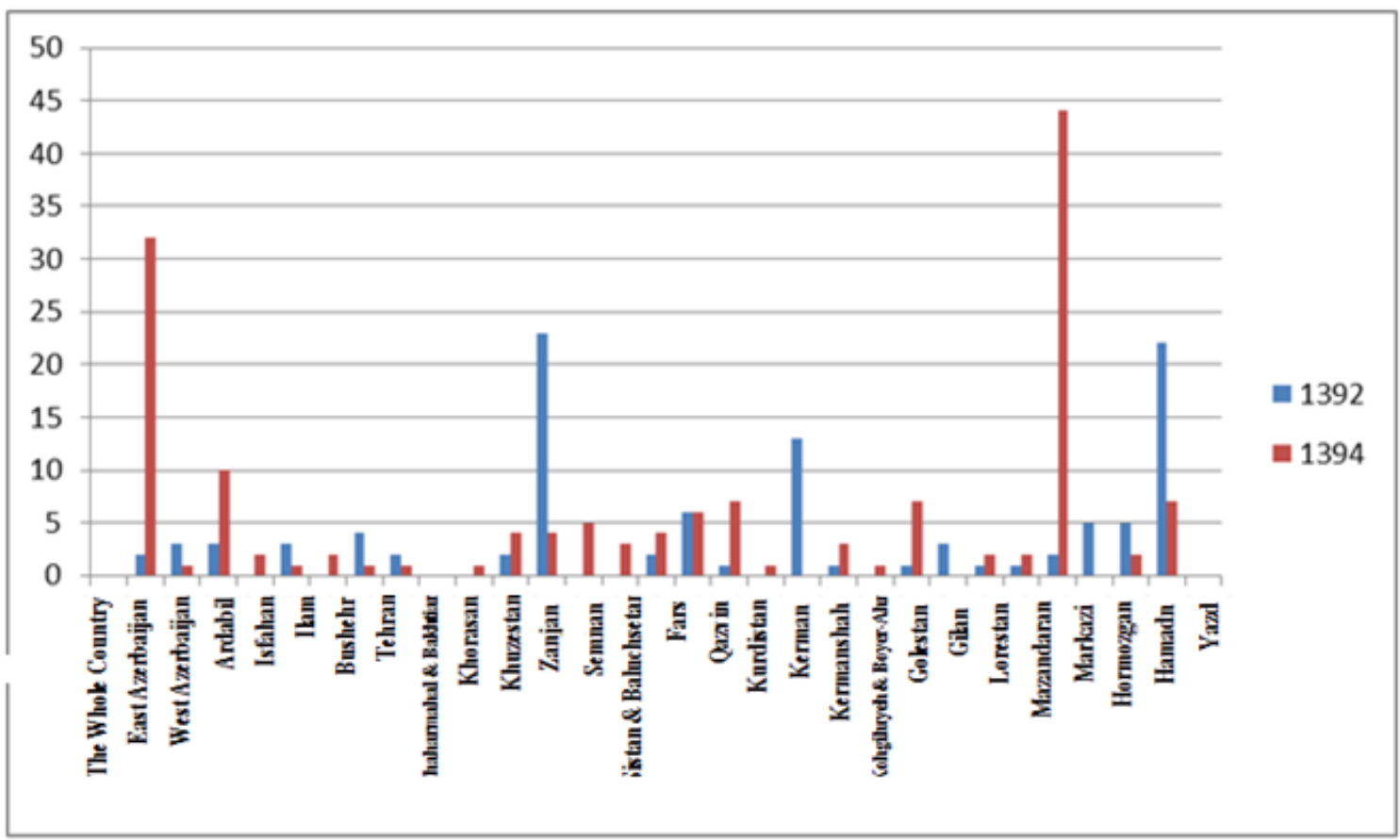

Diagram No.4 Investment Share in Computer Software from Total Investment with Provinces being separated. 2013 and 2015 (Percent)

As is shown in diagram above, the greatest increase of share is related to Hormozgan province with an increase of 1.7 percent in 2013 to 42.8 percent in 2015 which is a very significant increase. And the greatest share decrease of investment is related to Zanjan province with a decrease of 23.4 percent in 2011 to 3.2 percent in 2015. The mentioned share in the whole country has almost been the same in years of 2013 and 2015 which is equal to 0.9 percent.

\section{PENETRATION RATE OF COMPUTER}

According to a survey of passenger institutions and companies, about 1660 workshops were active in this field in the whole country in 2014. From among 1660 workshops, about 1300 of them were equipped with computers and 360 of them were without computers. In other words 78 percent of workshops had computers and 22 percent did not have. The workshops equipped with computers used them as following: 96 percent for doing activities inside workshop, 20 percent for typesetting works and 5 percent to connect to the internet. The significant point is penetration of computer into these kinds of institutions. 96 percent use of computer to do daily activities indicates effect of this tool and interest of workshops and necessity of it in improving function and increasing efficiency. (Table No.5)

Table no.5 Application of Internet in Passenger Institutions and Companies.2015 


\begin{tabular}{|c|c|c|c|c|c|c|c|c|c|c|c|}
\hline & \multicolumn{9}{|c|}{ Having Internet: Type of Use } & \multirow[t]{2}{*}{$\begin{array}{l}\text { Inaccess } \\
\text { ibility } \\
\text { to } \\
\text { Internet }\end{array}$} & \multirow[t]{2}{*}{$\begin{array}{c}\text { Number o } \\
\text { Employee } \\
\text { Using } \\
\text { Internet }\end{array}$} \\
\hline & Total & $\begin{array}{l}\text { Electr } \\
\text { onic } \\
\text { Mail }\end{array}$ & $\begin{array}{l}\text { Obtaini } \\
\text { ng } \\
\text { informa } \\
\text { tion }\end{array}$ & $\begin{array}{l}\text { Providin } \\
\text { g } \\
\text { Informat } \\
\text { ion }\end{array}$ & $\begin{array}{l}\text { Bank or } \\
\text { Financial } \\
\text { Affairs }\end{array}$ & $\begin{array}{c}\text { Doing } \\
\text { Governmenta } \\
1 \text { Affairs }\end{array}$ & $\begin{array}{l}\text { Customer } \\
\text { Services } \\
\text { and } \\
\text { Delivery }\end{array}$ & $\begin{array}{c}\text { Provision } \\
\text { of } \\
\text { Materials } \\
\& \\
\text { Requisite } \\
\text { s }\end{array}$ & $\begin{array}{l}\text { Oth } \\
\text { er }\end{array}$ & & \\
\hline 1300 & 64 & 81 & 27 & 15 & 5 & 0 & 24 & 0 & 9 & 1237 & 576 \\
\hline $\begin{array}{c}\text { Perce } \\
\text { nt }\end{array}$ & 8.9 & 32.8 & 43.1 & 23.6 & 6.7 & 0.0 & 35.5 & 0.0 & $\begin{array}{c}14 . \\
1\end{array}$ & 95.1 & 6.5 \\
\hline
\end{tabular}

Reference: Statistics Center of Iran and Computations of Author

Moreover from among 4481 employees using computer, 575 of them (6.5) used internet as well. In table No.5 the number of computer using workshops having access to internet is shown with provinces being separated.

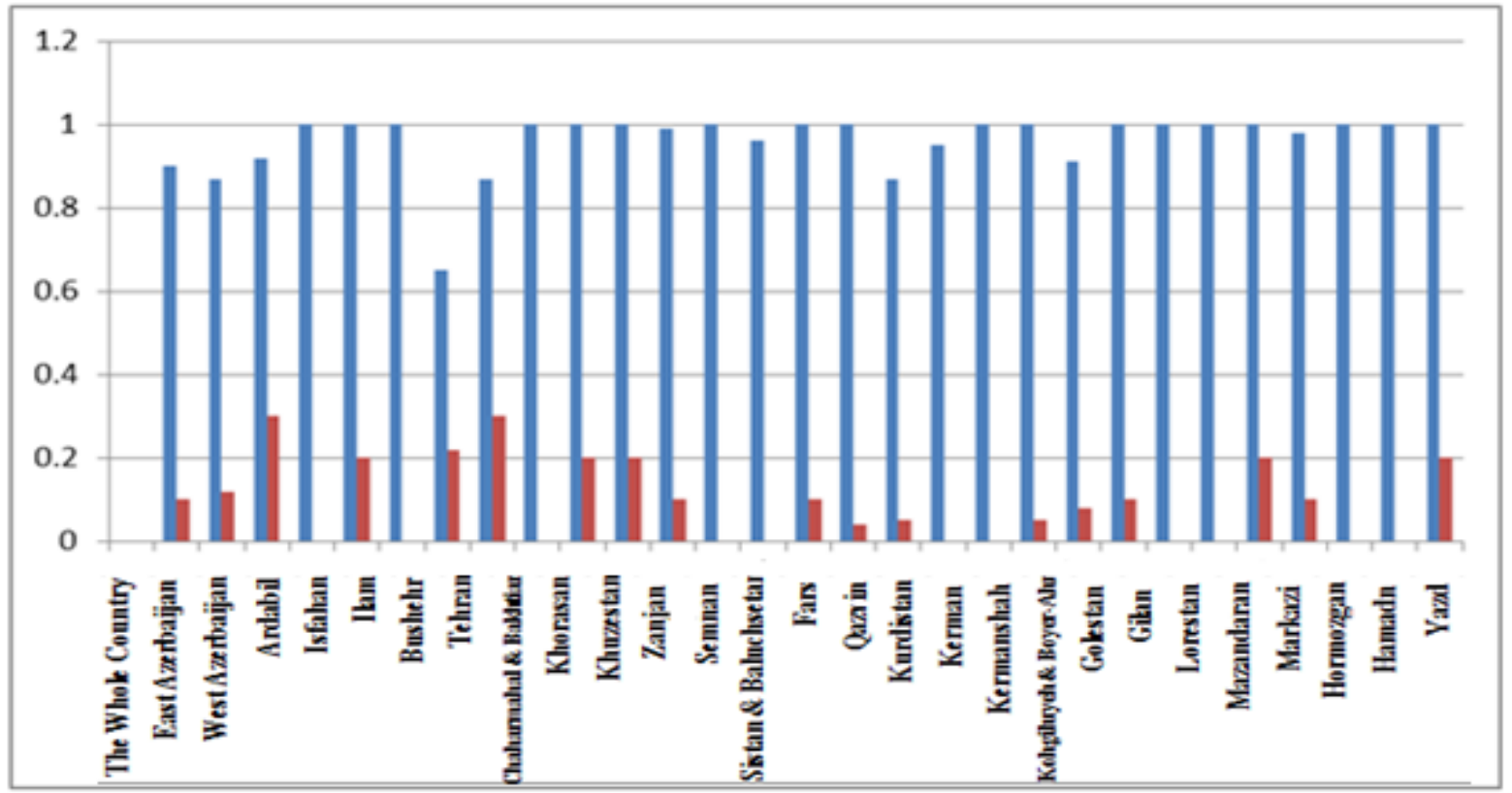

Diagram No.5 the Rate of Internet Use in Passenger Institutions and Companies.2015

As can be seen in the diagram above except a few numbers of provinces, other ones despite of having computers don't have access to internet. Comparing application of internet and computer points out that there is not a strong correlation between computer and internet in workshops and it seems that persons 
active in this filed pay more attention to capabilities and advantages of computer. The important point is that internet is mostly used to satisfy customers; escalation internet penetration rate and interest of volunteers to use internet to do activities has been effective in companies to give greater attention to this type of application.

\section{CONCLUSION}

Transport section can highly assist the development of country by creating required fields to increase transport level and create required facilities to develop investments and other similar activities. In this regard utilizing novel technologies such as development of Information Technology, active information networks and using computer systems can help transport system. In the present paper impact of Communication and information technology on value added of road transport sector in different provinces of country was studied. This research was conducted to find the answers of the following questions:

1- Does IT affect on function of road transport sector?

2- Is elasticity of production of transportation different as compared with ICT sub-sections (software, hardware, communication)?

Therefore in this research most studies are conducted in developed countries than developing countries. Most empirical studies confirm positive effects of ICT on transport sector in developing countries and state that he countries having complementary factors such as physical capital and human capital, utilize ICT more than other countries. Therefore it can be said that although passenger companies use computer but the use of internet is not very prevalent among them and there is no strong correlation between computer and internet in passenger companies. The important point is that internet is mostly used to satisfy customers; escalation internet penetration rate and interest of volunteers to use internet to do activities has been effective in companies to give greater attention to this type of application. Therefore investment in other that ICT, human capital, population growth rate, ICT investment, ICT expenditure and hardware and software investment have positive and significant effect on value added of passenger transport sector. Therefore investment in ICT can have very important and decisive effects on transport sector. The following suggestions are given according to the findings:

1- Development and improvement of using ITS (Intelligent Transport Systems) to support public transport through:

- Guidance of research and allocation of resources in combined transport, intelligent travels and so on.

- $\quad$ Providing prescription-requisites and prescription-conditions of ICT-based activities in combined transport, intelligent travels and so on.

- $\quad$ Providing prescription-requisites and prescription-conditions of ICT-based activities in public transport.

- Escalating charm of public transport through developing and utilizing systems to access information.

3- Improvement of efficiency in transportation through using ICT which must be combined with management of demand side; this combination decreases environmental impacts. The reason of such a decrease is travel time reduction and network capacity increase by ITS.

4- Promotion and extension of virtual meetings will probably have more effective electronic application in reducing environmental impacts of passenger transport.

\section{REFERENCES}

Saffar Zadeh, Mahmud. Hedayati, Javad (2014), Investigating Problems and Difficulties of Transit of Goods from Iran, Ministry of Road and Transportation Research and Education Center. 
Ayati, Ismail (2009). Mutual Relations between Ground Transportation and Economy of Country and Special Position of Khorasan Province, Conference for Position of Ground Transportation in Economy of Country, Ministry of Road and Transportation Research and Education Center.

Transportation and Terminals Organization, (2015), Changes of Transportation System and International Markets of Transportation in the Past 20 years and the most important Policies of Coming Decade of Transportation, Center for Teaching and Research.

Clark, C. (1957), "Transport: maker and breaker of cities", town planning review, No. 28, PP. 237-250

Dittmar, Hank et al. (2014), "An Introduction to Transit-Oriented Development", the New Transit Town; Best

Practices in Transit-Oriented Development, Edited by Hank Dittmar \& Gloria Ohland, Washington, London: Island Press, pp 1-18

Jacobs, Jane (1993), "Tod und Lebengrober Amerikanischer Stadte”, Frankfurt: Verlage uhlstein GmbH M.Daisa, James (2014), "Traffic, Parking and Transit- Oriented Development", the New Transit Town; Best

Practices in Transit-Oriented Development, Edited by Hank Dittmar \& Gloria Ohland, Washington, London: Island Press, pp 113-130

Tange, Kenzo (1970), “Architecture and Urban Design”, Zurich: Verlag Fur Architekture Artemis 